\title{
Carbon dioxide-enriched atmosphere enhances biomass accumulation and meristem production in the pioneer shrub Baccharis dracunculifolia (Asteraceae)
}

\author{
Camila Emiliane Mendes de Sá ${ }^{1}$, Daniel Negreiros ${ }^{1}$, Geraldo Wilson Fernandes ${ }^{1}$,
} Mariana Costa Dias ${ }^{1}$ and Augusto César Franco ${ }^{2}$

Received: August 21, 2013. Accepted: June 12, 2014

\begin{abstract}
The increase in atmospheric $\mathrm{CO}_{2}$ concentration predicted to the end of this century may cause several alterations on plant species development, which shall result in changes in the structure and function of plant communities. The present work aimed to investigate the effects of the increase in atmospheric $\mathrm{CO}_{2}$ concentration on the development of Baccharis dracunculifolia, a key pioneer Neotropical shrub. Seedlings of B. dracunculifolia were exposed to $720 \mathrm{ppm}$ of $\mathrm{CO}_{2}$ as well as to ambient concentration of $\mathrm{CO}_{2}$ (approximately $360 \mathrm{ppm}$ ) during 120 days in open top chambers. Growth and dry biomass accumulation were higher under elevated $\mathrm{CO}_{2}$ concentrations. As a response to $\mathrm{CO}_{2}$ enrichment, there was an increase of $134 \%$ in total dry mass, $208 \%$ in root dry mass and $152 \%$ in stem dry mass. The shrubby habit of $B$. dracunculifolia and the larger number of meristems produced under high $\mathrm{CO}_{2}$ promoted the increase in $137 \%$ in the number of branches. The present study contributes to the knowledge about how pioneer tropical plants may respond to increased atmospheric $\left[\mathrm{CO}_{2}\right]$ in environments with low nutrient limitation.
\end{abstract}

Keywords: climate change, elevated $\left[\mathrm{CO}_{2}\right]$, plant growth, pioneer species, resource allocation.

The predicted increase in atmospheric $\mathrm{CO}_{2}$ concentration $\left(\left[\mathrm{CO}_{2}\right]\right)$ may cause several physiological changes in plants, potentially resulting in profound changes in the function, structure and composition of plant communities (Zavaleta 2006). $\mathrm{C}_{3}$ plants grown under elevated $\left[\mathrm{CO}_{2}\right]$ usually differ in biomass accumulation, size and in resource allocation to different organs. In $\mathrm{C}_{3}$ species under elevated $\left[\mathrm{CO}_{2}\right]$ different studies reported a reduction in biomass allocation to leaves (Poorter 1993; Centritto et al. 1999; Cornelissen et al. 1999) and an increase in root biomass (Cheng et al. 2010). The intensification of photoassimilate production increases investment in underground sinks, which can result in a shift in the allocation of biomass to the roots under elevated $\left[\mathrm{CO}_{2}\right]$ (DeLucia et al. 1994). Furthermore, for leaves, the reduction in leaf area per leaf dry mass can be due the extra investment in photosynthetic apparatus (Centritto et al. 1999), and the accumulation of carbon-based compounds.
Plant responses to increasing $\left[\mathrm{CO}_{2}\right]$ may vary according to growth strategy. Fast-growing species require higher capture of nutrients and have a stronger carbon drain, and therefore respond more intensively to an increase in $\left[\mathrm{CO}_{2}\right]$ (Poorter 1993; Poorter \& Navas 2003). The increase in $\left[\mathrm{CO}_{2}\right]$ is likely to promote the dominance of invasive species (Smith et al. 2000; Polley et al. 2002; Weltzin et al. 2003), which can be stimulated to increase growth and leaf area as well as biomass of leaves, stems and roots (Ziska \& George 2004; Song et al. 2009). Several authors have postulated that climate change will have imbalanced effects among native and invasive plants (Weltzin et al. 2003). There is growing evidence that invasive plants tend to exhibit greater success in the colonization of natural ecosystems in response to raised $\mathrm{CO}_{2}$ levels (Smith et al. 2000; Belote et al. 2003; Weltzin et al. 2003). Some responses of invasive species to elevated $\left[\mathrm{CO}_{2}\right]$ include rises in germination rate (Zavaleta 2006), seedling establishment (Polley et al. 2002), biomass

\footnotetext{
${ }^{1}$ Laboratório de Ecologia Evolutiva e Biodiversidade, Departamento de Biologia Geral, ICB/Universidade Federal de Minas Gerais, Caixa Postal 486, Belo Horizonte, MG, 30161-970, Brazil. Fone: +55 (31) 3409-2592

${ }^{2}$ Departamento de Botânica, Universidade de Brasília, Caixa Postal 04457, Brasília, DF, 70904-970, Brazil.

Corresponding author: gw.fernandes@gmail.com
} 
production (Smith et al. 2000; Belote et al. 2003) and fecundity (Smith et al. 2000). Therefore, plant biological invasions could represent a significant side-effect of global climate change, with great consequences for the invaded communities.

Baccharis dracunculifolia DC. (Asteraceae) is a fastgrowing shrub, which is distributed from southeastern and southern Brazil to Argentina, Uruguay, Paraguay and Bolivia. This species occurs both in degraded areas and in early succession stages, in the transition zone between forest and grasslands (Müller et al. 2007; Negreiros et al. 2014). The species is an obligate seeder and plays a central role in the natural regeneration after disturbances such as fires (Galindez et al. 2009). It has been widely studied in various ecological aspects, including growth responses to nutrient availability (Negreiros et al. 2014) and interactions different guilds of insect herbivores (e.g., Fagundes et al. 2005; Espírito-Santo et al. 2007). Therefore, investigating the effects of increased atmospheric $\left[\mathrm{CO}_{2}\right]$ on this species is of particular interest, considering its importance both in the plant community and for the associated fauna.

This study aimed to investigate the effects of increased atmospheric $\mathrm{CO}_{2}$ concentration on the development of this native tropical species. An experiment was performed in Open Top Chambers (OTCs) with two different concentrations of $\mathrm{CO}_{2}$ (ambient $\left[\mathrm{CO}_{2}\right]$, with about $360 \mathrm{ppm}$ and increased $\left[\mathrm{CO}_{2}\right]$, about $720 \mathrm{ppm}$ ) in order to test the following hypotheses: 1) Biomass increase hypothesis, which predicts that under elevated atmospheric $\left[\mathrm{CO}_{2}\right]$ there would be higher biomass production in seedlings of $B$. dracunculifolia, given their characteristics of pioneer species and rapid growth (Müller et al. 2007; Negreiros et al. 2014), 2) Hypothesis of differential biomass allocation, according to which there would be a shift in the biomass allocation in plants grown under higher $\left[\mathrm{CO}_{2}\right]$ in comparison to the ones grown under ambient $\left[\mathrm{CO}_{2}\right]$. According to this hypothesis, $B$. dracunculifolia would increase root biomass in relation to the shoot biomass, since that in general plants respond to increased $\left[\mathrm{CO}_{2}\right]$ by allocating more biomass to the roots (Poorter 1993; Cheng et al. 2010).

In order to evaluate the effects of elevated $\left[\mathrm{CO}_{2}\right]$ on seedling development, mature achenes were manually collected from approximately 15 individuals of $B$. dracunculifolia located at the Vellozia Private Reserve (19 $16^{\prime} 45.7^{\prime \prime}$ S, $\left.43^{\circ} 35^{\prime} 27.8^{\prime \prime} \mathrm{W}\right)$, Serra do Cipó, Brazil. The achenes were homogenized and placed to germinate on a mixture of sand and vermiculite (2:3) in plastic trays and were moistened three times a day. This procedure was performed in a greenhouse, covered by a screen with a $30 \%$ reduction of light intensity, located at the surroundings of the Institute of Biological Sciences, Universidade Federal de Minas Gerais, Belo Horizonte, Brazil.

At the day of cotyledon leaves emergence (approximately four weeks after germination), seedlings were carefully transplanted to $1.7 \mathrm{~L}$ pots $(20 \times 12 \mathrm{~cm})$ filled up with sand and vermiculite (2:3). Three seedlings were planted in each pot. Immediately after transplantation, the pots were placed into four OTCs installed in the greenhouse (45 pots per chamber). The chambers consisted of a frame of circular metallic rings of $1.5 \mathrm{~m}$ diameter and $1.5 \mathrm{~m}$ high covered with transparent polycarbonate. The sources of $\mathrm{CO}_{2}$ used were pressurized cylinders with $99 \% \mathrm{CO}_{2}, 35.69 \mathrm{KgF} . \mathrm{cm}^{-2}$. The temperature and humidity inside the chambers were continuously monitored during the experiment. Two chambers were maintained at ambient $\left[\mathrm{CO}_{2}\right](\sim 360 \mathrm{ppm})$, while the other two were submitted to a continuous injection of $\mathrm{CO}_{2}$, and kept at twice this concentration ( $\left.720 \mathrm{ppm}\right)$. The $\mathrm{CO}_{2}$ concentration was continuously monitored using an infrared gas analyser (SBA-4 $\mathrm{CO}_{2}$ Analyzer, PP SYSTEMS) and the software Remote Integrated Control System (RICS 3.7, Evco).

The pots were watered with distilled water to maintain the substrate moisture close to saturation, usually three times a week, through the weighing method, following Novais et al. (1991). This method consists of weighing the pots with sufficient water for saturation, and weighing them again after part of the water is consumed and/or evaporated in order to calculate the volume of water required for each pot. In the second and third weeks of growth within the chambers, the plants were irrigated with $50 \mathrm{~mL}$ of nutrient solution modified from Hoagland \& Arnon (1950), at $1 / 4$ of ionic strength. From the fourth week, $350 \mathrm{~mL}$ of this solution at the same concentration was added to the pots every fifteen days, after washing the substrate with distilled water. To reduce the possible effects of microenvironmental differences between the chambers, the pots were changed weekly between the chambers with the same $\left[\mathrm{CO}_{2}\right]$ treatment. In order to minimize the effects of possible microclimate heterogeneity inside the chambers, we performed a rotation of the pots within the chambers three times a week.

Each pot represented one experimental unity (considering the mean of the three seedlings in each pot). Sampling was performed 15, 30, 60, 90 and 120 days after the beginning of the experiment. In each treatment, ten pots were randomly chosen for sampling (five pots per chamber) at each sampling date. To evaluate the biomass accumulation and growth of $B$. dracunculifolia throughout the experimental period, we measured seedling height, total dry mass of leaves, stems and roots, total number of leaves, number of branches from the main axis, number of nodes and average length of internodes. To obtain the total leaf area, the collected shoots were immediately taken to the laboratory where the leaves were detached from the stems (at the normal point of abscission), scanned, and the total leaf area was determined by using the software SigmaScan Pro Image Analysis 5.0 (SSI, California). The roots were separated by carefully washing them with water on a sieve with $3 \mathrm{~mm}$ of mesh aperture, followed by subsequent inspection with the aid of a stereomicroscope. Brush and tweezers were used to completely remove substrate particles adhered to the roots. 
Dry mass of leaves, stems and roots were measured in a microbalance (model SE2, accuracy of $0.1 \mu \mathrm{g}$ ) after drying the material in an oven at $60^{\circ} \mathrm{C}$ until constant mass was reached.

To assess biomass allocation we calculated the root:shoot ratio (R:S ratio), root mass ratio (RMR), stem mass ratio (SMR) and leaf mass ratio (LMR), according to the following equations (Hunt 1982): $R: S$ ratio $=R_{M} /\left(L_{M}+S_{M}\right)$; $R M R=R_{M} / M ; S M R=S_{M} / M ; L M R=L_{M} / M$; where: $R_{M}=$ dry mass of roots, $S_{M}=$ dry mass of stem; $L_{M}=$ dry mass of leaves $/ M=$ total dry mass $\left(R_{M}+L_{M}+S_{M}\right)$.

All variables were subjected to Liliefors and Lavene analyses to check the parametric assumptions, and transformations were employed when necessary to stabilize variances and normalize the data (Quinn \& Keough 2002). To evaluate the differences between the two $\mathrm{CO}_{2}$ treatments, we used the Student's t-test. To test for differences between treatments over time we performed a two-way ANOVA (Quinn \& Keough 2002) using the averages of the logarithmized variables (Hoffmann \& Poorter 2002).

The exposure of seedlings of $B$. dracunculifolia to elevated $\left[\mathrm{CO}_{2}\right]$ resulted in a significant increase in biomass after 120 days of experiment. After that time, seedlings grown under elevated $\left[\mathrm{CO}_{2}\right]$ showed higher values of total dry mass (increase of 134\%), root dry mass (increase of $208 \%$ ), stem dry mass (increase of $152 \%$ ), leaf dry mass (increase of 97\%), total leaf area (increase of $49 \%$ ), plant height (increase of 52\%), number of leaves (increase of 63\%), number of branches (increase of 137\%), number of nodes (increase of 34\%) and length of internodes (increase of 17\%) than plants grown in ambient $\left[\mathrm{CO}_{2}\right]$ (Table 1 ).

After 120 days, plants grown under elevated $\left[\mathrm{CO}_{2}\right]$ also allocated more biomass to the underground component, showing a significant increase in R:S ratio (increase of 38\%)
(Table 1). Under high $\left[\mathrm{CO}_{2}\right]$, B. dracunculifolia showed a higher root mass ratio (increase of $31 \%$ ) and lower leaf mass ratio (reduction of $18 \%$ ), whereas no significant difference in stem mass ratio were found between the two treatments (Table 1).

In addition to the effect of $\mathrm{CO}_{2}$ enrichment, growth responses were time-dependent (Table 2). There was also a significant " $\mathrm{CO}_{2}$ treatment" * "time" interaction for root mass accumulation, number of leaves, number of branches and number of nodes (Table 2).

Baccharis dracunculifolia responded to elevated atmospheric $\left[\mathrm{CO}_{2}\right]$ by increasing the total plant dry mass, supporting the biomass increase hypothesis. The $134 \%$ increase in total biomass of individuals grown under high $\left[\mathrm{CO}_{2}\right]$ in relation to controls exceeded the averages reported by Poorter (1993) for different groups of $C_{3}$ plants from several regions of the planet (slow and fast growing herbaceous, woody, wild and crop species), which ranged between $23 \%$ and 58\%. Ziska et al. (1991) observed a significant increase in total dry mass in four out of five $\mathrm{C}_{3}$ tropical species grown under high $\left[\mathrm{CO}_{2}\right]$, with values ranging from $10 \%$ to $172 \%$ after 3 months of development in similar $\mathrm{CO}_{2}$ levels. However, significant differences in growth of $B$. dracunculifolia did not occur before 120 days of exposure to high $\left[\mathrm{CO}_{2}\right]$ (data not shown). The response time to $\mathrm{CO}_{2}$ enrichment seems to vary according to the habit and physiology of each species (Centritto et al. 1999; Hoffmann et al. 2000).

The increased growth of $B$. dracunculifolia under elevated $\left[\mathrm{CO}_{2}\right]$ was primarily due to the increase in root biomass, since this parameter had the highest increase of biomass in elevated $\left[\mathrm{CO}_{2}\right]$ compared to ambient $\left[\mathrm{CO}_{2}\right]$. This larger investment in root biomass was reflected in an increase in root:shoot ratio in elevated $\left[\mathrm{CO}_{2}\right]$, and this

Table 1. Biomass production and partitioning in seedlings of B. dracunculifolia subjected to 120 days of ambient $(\sim 360 \mathrm{ppm})$ and elevated $(\sim 720 \mathrm{ppm}) \mathrm{CO}_{2}$ concentrations $\left(\left[\mathrm{CO}_{2}\right]\right)$. Measurements represent the mean \pm standard error $(\mathrm{n}=10)$. Significant differences between means are indicated by the $p$ value: ${ }^{*} p<0.05,{ }^{* *}$ $p<0.01,{ }^{* * *} p<0.001$, determined by Student's t-test.

\begin{tabular}{|c|c|c|}
\hline & Ambient $\left[\mathrm{CO}_{2}\right]$ & Elevated $\left[\mathrm{CO}_{2}\right]$ \\
\hline Total dry mass (mg) ${ }^{* * *}$ & $467.60 \pm 65.05$ & $1092.08 \pm 118.24$ \\
\hline Root dry mass $(\mathrm{mg})^{* * *}$ & $74.53 \pm 13.07$ & $229.38 \pm 33.42$ \\
\hline Stem dry mass $(\mathrm{mg})^{* * *}$ & $160.95 \pm 30.17$ & $405.13 \pm 40.75$ \\
\hline Leaf dry mass $(\mathrm{mg})^{* * *}$ & $232.11 \pm 28.74$ & $457.58 \pm 44.50$ \\
\hline Leaf area $\left(\mathrm{cm}^{2}\right)^{* *}$ & $78.49 \pm 8.44$ & $117.09 \pm 6.94$ \\
\hline Plant height $(\mathrm{cm})^{* *}$ & $21.70 \pm 2.46$ & $33.03 \pm 2.10$ \\
\hline Number of leaves (un) ${ }^{* * *}$ & $22.33 \pm 2.11$ & $36.50 \pm 2.04$ \\
\hline Number of shoots (un) ${ }^{* *}$ & $2.27 \pm 0.54$ & $5.38 \pm 0.75$ \\
\hline Number of nodes (un) ${ }^{* * *}$ & $22.33 \pm 1.35$ & $29.83 \pm 1.03$ \\
\hline Internode lenght $(\mathrm{mm})$ * & $9.29 \pm 0.55$ & $10.89 \pm 0.46$ \\
\hline Root:shoot ratio ${ }^{* *}$ & $0.185 \pm 0.020$ & $0.255 \pm 0.013$ \\
\hline Root mass ratio ${ }^{* *}$ & $0.154 \pm 0.015$ & $0.202 \pm 0.009$ \\
\hline Stem mass ratio & $0.326 \pm 0.026$ & $0.374 \pm 0.005$ \\
\hline Leaf mass ratio * & $0.520 \pm 0.038$ & $0.424 \pm 0.006$ \\
\hline
\end{tabular}


Table 2. Results of two-way ANOVA to test for the effects of $\mathrm{CO}_{2}$ treatments (elevated and ambient $\left.\left[\mathrm{CO}_{2}\right]\right)$ and time (15, 30, 60, 90, 120 days after $\mathrm{CO}_{2}$ enrichment) on growth parameters of Baccharis dracunculifolia. NS = non-significant.

\begin{tabular}{|c|c|c|c|c|c|c|}
\hline & \multicolumn{2}{|c|}{$\left[\mathrm{CO}_{2}\right]$ treatment } & \multicolumn{2}{|c|}{ Time } & \multicolumn{2}{|c|}{$\left[\mathrm{CO}_{2}\right]$ treatment $*$ Time } \\
\hline & F-ratio & $p$-value & F-ratio & $p$-value & F-ratio & $p$-value \\
\hline Total dry mass & 10.40 & 0.002 & 739.04 & 0.000 & 2.30 & NS \\
\hline Root dry mass & 16.45 & 0.000 & 558.95 & 0.000 & 4.14 & 0.004 \\
\hline Stem dry mass & 10.09 & 0.002 & 698.03 & 0.000 & 2.47 & NS \\
\hline Leaf dry mass & 8.43 & 0.005 & 739.30 & 0.000 & 1.52 & NS \\
\hline Leaf area & 5.09 & 0.027 & 718.92 & 0.000 & 1.29 & NS \\
\hline Plant height & 11.05 & 0.001 & 630.79 & 0.000 & 2.01 & NS \\
\hline Number of leaves & 11.99 & 0.001 & 447.15 & 0.000 & 8.60 & 0.000 \\
\hline Number of shoots & 11.83 & 0.001 & 66.83 & 0.000 & 4.88 & 0.001 \\
\hline Number of nodes & 5.15 & 0.026 & 933.07 & 0.000 & 3.89 & 0.006 \\
\hline Internode lenght & 9.89 & 0.002 & 269.47 & 0.000 & 2.16 & NS \\
\hline
\end{tabular}

result supported the hypothesis of differential biomass allocation. The greater biomass allocation to roots in relation to shoots also evidenced the expressive importance of the underground component in the increase of total biomass in response to increased availability of $\mathrm{CO}_{2}$. This pattern has been reported in other studies (e.g., Centritto et al. 1999; Cornelissen et al. 1999). On the other side, the increase in stem biomass in individuals grown under elevated $\left[\mathrm{CO}_{2}\right]$ may be more associated with the greater increase in the number of nodes and branches, than to increases in internodes length. In contrast, in a study of tree species grown under elevated $\left[\mathrm{CO}_{2}\right]$ in OTCs, increased shoot biomass was associated with rapid growth in height, mainly due to increased elongation of internodes (Ceulemans et al.1995). In $B$. dracunculifolia, increasing the number of nodes allowed an increase in the number of branches as a result of increased availability of meristems. The shrubby habit of $B$. dracunculifolia may have favored such response. Considering that the interaction between " $\mathrm{CO}_{2}$ treatment" and "time" showed a significant difference for the root dry mass and number of leaves, branches and nodes, we can infer that the relative growth rate (RGR) of B. dracunculifolia in elevated $\left[\mathrm{CO}_{2}\right]$ treatment was greater than in ambient $\left[\mathrm{CO}_{2}\right]$ treatment. A higher value of RGR may confer advantages in soil occupation and in resources capturing, in addition to facilitating the rapid completion of the plant's life cycle, essential condition for pioneer species.

Baccharis dracunculifolia produces new branches throughout the year and is regarded as having a complex architecture, with large formation of fourth-level shoots, which can be considered as an indicator of the amount of meristems in a plant (Espírito-Santo et al. 2007). The increase in the number of nodes and branches observed in this study suggests that the predicted rise in atmospheric $\left[\mathrm{CO}_{2}\right]$ could increase the amount of meristems available to the plant, which could lead to greater investment in reproductive structures. Since $B$. dracunculifolia displays an obligate seeder regeneration strategy (Galindez et al. 2009), the increased availability of meristems could, in an elevated $\left[\mathrm{CO}_{2}\right]$ environment, boost an increase in flower production and in the number of seeds and consequently the colonization potential of this species. Obligate seeder species possess, in addition to rapid growth, a competitive advantage in less shaded environments (Chew \& Bonser 2009). These characteristics, associated with a high phenotypic variability, may enhance the ability of $B$. dracunculifolia to behave as an invasive species (Negreiros et al. 2014). The great plasticity shown by invasive species allow them to adjust the allocation of biomass (Song et al. 2009) or maximize the production of seeds, favoring the colonization of habitats after disturbances (Chew \& Bonser 2009). In a future scenario of changes in resource availability by increased $\left[\mathrm{CO}_{2}\right]$, species with large plastic capacity may have greater success in establishment, by changing physiological or morphological traits to maintain the balance of resource acquisition. The present study contributes to the knowledge about how potentially invasive tropical plants may respond to increased atmospheric $\left[\mathrm{CO}_{2}\right]$ in environments with low nutrient limitation.

\section{Acknowledgements}

We are grateful to José Pires Lemos-Filho for logistical help, Marcel Giovanni Costa França and Fernando Augusto de Oliveira e Silveira for critical review of earlier versions of the manuscript, Renata Martins Belo for technical assistance during the experiments and William Arthur Hoffmann for advices on statistical analyses. We thank Conselho Nacional de Desenvolvimento Científico e Tecnológico (479485/2012-7, 130254/2008-8, 163020/20132, 457519/2012-6, 403781/2012-4, 303352/2010-8, 563304/2009-3, 558250/2009-2), Coordenação de Aperfeiçoamento de Pessoal de Nível Superior, Fundação de 
Amparo à Pesquisa do Estado de Minas Gerais (APQ-0319913, APQ-04105-10, APQ-01278/08), FAPEMIG/FAPESP/ FAPESPA/VALE S.A (RDP-00048-10) and US Fish and Wildlife Service for financial support.

\section{References}

Belote, R.T.; Weltzin, J.F. \& Norby, R.J. 2003. Response of an understory plant community to elevated $\left[\mathrm{CO}_{2}\right]$ depends on differential responses of dominant invasive species and is mediated by soil water availability. New Phytologist 161: 827-835.

Centritto, M.; Lee, H.S.J. \& Jarvis, P.G. 1999. Increased growth in elevated $\left[\mathrm{CO}_{2}\right]$ : an early, short-term response? Global Change Biology 5: 623-633.

Ceulemans, R.; Jiang, X.N. \& Shao, B.Y. 1995. Growth and physiology of one-year old Poplar (Populus) under elevated atmospheric $\mathrm{CO}_{2}$ Levels. Annals of Botany 75: 609-617.

Cheng, L.; Zhu, J.; Chen, G.; Zheng, X.; Oh, N.H.; Ruffy, T.W.; Richter, D.B. \& Hu, S. 2010. Atmospheric $\mathrm{CO}_{2}$ enrichment facilitates cation release from soil. Ecology Letters 13: 284-291.

Chew, S.J. \& Bonser, S.P. 2009. The evolution of growth rate, resource allocation and competitive ability in seeder and resprouter tree seedlings. Evolutionary Ecology 23: 723-735.

Cornelissen, J.H.C.; Carnelli, A.L. \& Callaghan, T.V. 1999. Generalities in the growth, allocation and leaf quality responses to elevated $\mathrm{CO}_{2}$ in eight woody species. New Phytologist 141: 401-409.

DeLucia, E.H.; Callaway, R.M. \& Schlesinger, W.H. 1994. Offsetting changes in biomass allocation and photosynthesis in ponderosa pine (Pinus ponderosa) in response to climate change. Tree Physiology 14: 669-677.

Espírito-Santo, M.M.; Neves, F.S.; Andrade-Neto, F. \& Fernandes, G.W. 2007. Plant architecture and meristem dynamics as the mechanisms determining the diversity of gall-inducing insects. Oecologia 153: 353-364.

Fagundes, M.; Neves, F.S. \& Fernandes, G.W. 2005. Direct and indirect interactions involving ants, insect herbivores, parasitoids and the host plant Baccharis dracunculifolia (Asteraceae). Ecological Entomology 30: 28-35.

Galindez, G.; Biganzoli, F.; Ortega-Baes, P. \& Scopel, A.L. 2009. Fire responses of three co-occurring Asteraceae shrubs in a temperate savanna in South America. Plant Ecology 202: 149-158.

Hoagland, R. \& Arnon, D.I. 1950. The water culture method for growing plants without soils. Berkeley, California Agricultural Experimental Station.
Hoffmann, W.A.; Bazzaz, F.A.; Chatterton, N.J.; Harrison, P.A. \& Jackson, R.B. 2000. Elevated $\mathrm{CO}_{2}$ enhances resprouting of a tropical savanna tree. Oecologia 123: 312-317.

Hoffmann, W.A. \& Poorter, H. 2002. Avoiding bias in calculations of relative growth rate. Annals of Botany 80: 37-42.

Hunt, R. 1982. Plant growth curves: the functional approach to plant growth analysis. London, Edward Arnold.

Müller, S.C.; Overbeck, G.E.; Pfadenhauer, J. \& Pillar, V.D. 2007. Plant functional types of woody species related to fire disturbance in forestgrassland ecotones. Plant Ecology 189: 1-14.

Negreiros, D.; Esteves, D.; Fernandes, G.W.; Berbara, R.L.L.; Oki, Y.; Vichiato, M. \& Chalub, C. 2014. Growth-survival tradeoff in the widespread tropical shrub Baccharis dracunculifolia (Asteraceae) in response to a nutrient gradient. Tropical Ecology 55: 167-176.

Novais, R.F.; Neves, J.C.L. \& Barros, N.F. 1991. Ensaio em ambiente controlado. Pp. 189-253. In: Oliveira, A.J.; Garrido, W.E.; Araújo, J.D. \& Lourenço, S. (Eds.). Métodos de pesquisa em fertilidade do solo. Brasília, EMBRAPA-SEA.

Polley, H.W.; Johnson, H.B. \& Tischler, C.R. 2002. Woody invasion of grasslands: evidence that $\mathrm{CO}_{2}$ enrichment indirectly promotes establishment of Prosopis glandulosa. Plant Ecology 164: 85-94.

Poorter, H. 1993. Interspecific variation in the growth response of plants to an elevated ambient $\mathrm{CO}_{2}$ concentration. Vegetatio 104/105: 77-97.

Poorter, H. \& Navas, M.L. 2003. Plant growth and competition at elevated $\mathrm{CO}_{2}$ : on winners, losers and functional groups. New Phytologist 157: 175-198.

Quinn, G.P. \& Keough, M.J. 2002. Experimental design and data analysis for biologists. Cambridge, Cambridge University Press.

Smith, S.D.; Huxman, T.E.; Zitzer, S.F.; Charlet, T.N.; Houseman, D.C.; Coleman, J.S.; Fenstermaker, L.K.; Seemann, J.R. \& Nowak, R.S. 2000. Elevated $\mathrm{CO}_{2}$ increases productivity and invasive species success in an arid ecosystem. Nature 408: 79-82.

Song, L.; Wu, J.; Li, C.; Li, F.; Peng, S. \& Chen, B. 2009. Different responses of invasive and native species to elevated $\mathrm{CO}_{2}$ concentration. Acta Oecologica 35: 128-135.

Weltzin, J.F.; Belote, R.T. \& Sanders, N. 2003. Biological invaders in a greenhouse world: will elevated $\mathrm{CO}_{2}$ fuel plant invasions? Frontiers in Ecology and the Environment 1: 146-153.

Zavaleta, E.S. 2006. Shrub establishment under experimental global changes in a California grassland. Plant Ecology 184: 53-63.

Ziska, L.H.; Hogan, K.P.; Smith, A.P. \& Drake, B.G. 1991. Growth and photosynthetic response of nine tropical species with long-term exposure to elevated carbon dioxide. Oecologia 86: 383-389.

Ziska, L.H. \& George, K. 2004. Rising carbon dioxide and invasive, noxious plants: potential threats and consequences. World Resource Review 16: $427-447$. 